\title{
Petrography and mineralogy of kimberlites and kamafugites from the Alto Paranaíba Igneous Province, Minas Gerais, Brazil: Preliminary studies.
}

\author{
Araujo, A.L.N. ${ }^{1}$, Gaspar, J.C. ${ }^{1}$ \& Bizzi, L.C. ${ }^{2}$
}

1. Department of Geology, University of Brasília, Campus Universitário Darcy Ribeiro, Asa Norte, Brasília, DF, Brazil - CEP: 70910-900

2. SOPEMI S.A., SIA trecho 2, 1591, Brasília, DF, Brazil

The southwestern flank of the São Francisco craton in SE Brazil is intruded by the Cretaceous Alto Paranaíba Igneous Province (APIP; Figure 1) which is part of an approximately $2000 \mathrm{~km}$ long NW-SE trending corridor of alkaline magmatism (Bardet, 1977; Gibson et al, 1995). Emplacement ages report for the APIP range ca. 80-120 Ma (Bizzi, 1995), with the majority of the age data clustering at 80-90 Ma (Gibson et al, 1995). The voluminous alkaline magmatism in the APIP has been ascribed to the influence of hot spot activity and both evidence for mantle heterogeneity and distribution of lithological types within the Province appear related to different depths of magma generation and metasomatic imprint on the mantle sources. Mineralized kimberlites have been reported by Gonzaga \& Tompkins (1991) and many significant alluvial diamond deposits are know to occur within the limits of the Province.

Some sixty pipes have been selected from the wide variety of rock types comprises the APIP (dykes, pipes, plugs, diatremes, lava flows associated or not to pyroclastic deposits and large plutonic complexes) for this study. Macroscopically, most of the rocks present massive black to brown aspect with olivine macrocrystals and sometimes with lesser amounts of visible pyroxene and ilmenite. They texture is inequigranular, they are often carbonatized, and xenoliths contained therein comprises mainly lherzolites and dunite, country rocks clasts, and fragments of cognate phases.

The rocks have been classified on the basis of detailed petrography and mineral chemistry as kimberlites and kamafugites (ugandites and mafurites). The kimberlites have two olivine populations of different morphologies (rounded olivine macrocrysts and smaller subhedral phenocrysts) and their groundmass comprises olivine, ilmenite, phlogopite, spinel group minerals, perovskite, serpentine, carbonate, monticellite, iddingsite, apatite, and clay minerals. In some of the samples phlogopite and ilmenite macrocrysts have been identified. The kamafugitic rocks present euhedral to subhedral olivine grains and their groundmass comprises pyroxene, olivine, phlogopite, leucite and/or kalsilite, spinel group minerals, perovskite, serpentine, apatite, carbonate and clay minerals. The mafurite end-members are characterized by fresh leucite and/or leucite pseudomorphos replaced by analcime, zeolite, and clay minerals and minor amounts of kalsilite may occur. In the ugandite end-members kalsilite is the only felsic phase present.

Spinels, ilmenite, olivine, pyroxene, leucite, and kalsilite have been probed. Four spinel group minerals have been identified. Their compositional variation and the relation between magnesium number (\#mg) and chrome number (\#cr) for kimberlites and kamafigites spinels are ilustred in figure 2 and 3, respectively. Ilmenite was only recognized in kimberlitic rocks. Figure 4 shows the ilmenite probe data in the $\mathrm{MgTiO}_{3}-\mathrm{FeTiO}_{3}-\mathrm{MnTiO}_{3}$ projection and illustrates their affinity to kimberlitic ilmenites reported elsewhere. The kimberlite olivines have compositions within the $\mathrm{FO}_{85}$ to $\mathrm{FO}_{92}$ range (macrocrysts typically Fo90-92 and phenocrysts Fo $_{85-92}$ ) which are typical of kimberlitic olivines. Kamafugitic olivines are within the Fo85-90 range, which is comparable to olivines reported for similar rocks in southwestern Uganda, Arizona, and Italy. Pyroxenes from the kamafugitic rocks are mainly diopside and show little compositional variation. Analyses of fresh leucite $\left(\mathrm{SiO}_{2} \rightarrow 53.7-55.2, \mathrm{Al}_{2} \mathrm{O}_{3} \rightarrow 20.39-22.4, \mathrm{~K}_{2} \mathrm{O} \rightarrow 17.2-21.1\right)$ could be 
performed only in the samples from the Omega-06 pipe. The other pipes contain only leucite pseudomorphs. Kalsilite $\left(\mathrm{SiO}_{2} \rightarrow 37.9-38.8, \mathrm{Al}_{2} \mathrm{O}_{3} \rightarrow 28.5-29.1, \mathrm{~K}_{2} \mathrm{O} \rightarrow 27.1-28.5\right)$ occurs interstitially and as aggregates or single crystals. Their compositional range is similar to that reported for kamafugitc kalsilites in Uganda and Italy.

\section{Conclusions}

On the basis of petrography and mineral chemistry the rocks of the Alto Paranaiba Igneous Province could be divided in three groups: kimberlites, mafurites and ugandites, with a marked dominance of kamafugitic rocks over kimberlites. On a regional scale, the petrographic characteristics and distribution of igneous activity along this craton margin are comparable to that in south western Uganda and southern Africa, the implication being that the prospectivity of the area for economic primary diamond occurrences should be down-graded.

\section{References}

Bardet, M.G., 1977. Geologie du diamant. Troisieme parte: gisements de diamants D'Asie, D’Amerique, D’Europe et D'Australasie. Bureau Recherches Geologiques et Minieres, Memoire 83, 169 p.

Bizzi, L.A., Wit, M.J., Smith, C.B., Macdonald, I. \& Armstrong, R.A.; 1995. Heterogeneous enriched mantle materials and Dupal-Tipe magmatism along the SW margin of the São Francisco Craton, Brazil. J. Geodyn. 20: 469-491.

Gonzaga, G.M. \& Tompkins, L.A.; 1991. Geologia do diamante. In: Principais Depósitos minerais do Brasil, 4A. DNPM-CPRM.

Gibson, S.A., Thompson, R.N., Leonardos, O.H., Dickin, A.P. \& Mitchell, J.G.; 1995. The late cretaceous impact of the Trindade mantle plume: evidence from large-volume, mafic, potassic magmatism in SE Brazil. J. Petrol. 36: 189-229.

Tompkins \& Haggerty, S.E.; 1985. Groundmass oxide minerals in the koidu kimberlite dikes, Sierra Leone, West Africa. Contrib. Mineral. Petrol. 25: 355-416.

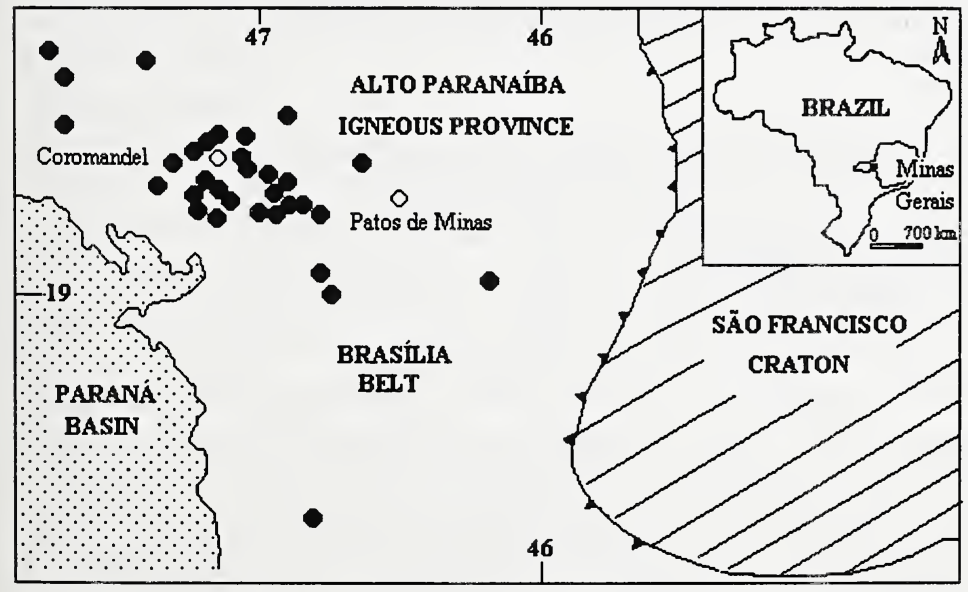

Figure 1: Location of Alto Paranaíba Igneous Province. • Cretaceous complexes. Adapted from Gibson et al (1995). 


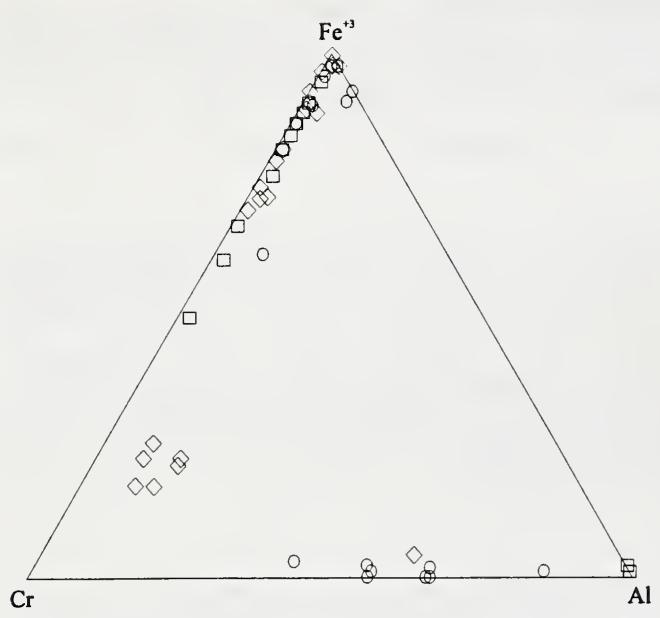

Figure 2: $\mathrm{Fe}^{+3}-\mathrm{Cr}-\mathrm{Al}$ diagram for spinels. Circle, kimberlite; square, mafurite; diamond, ugandite.

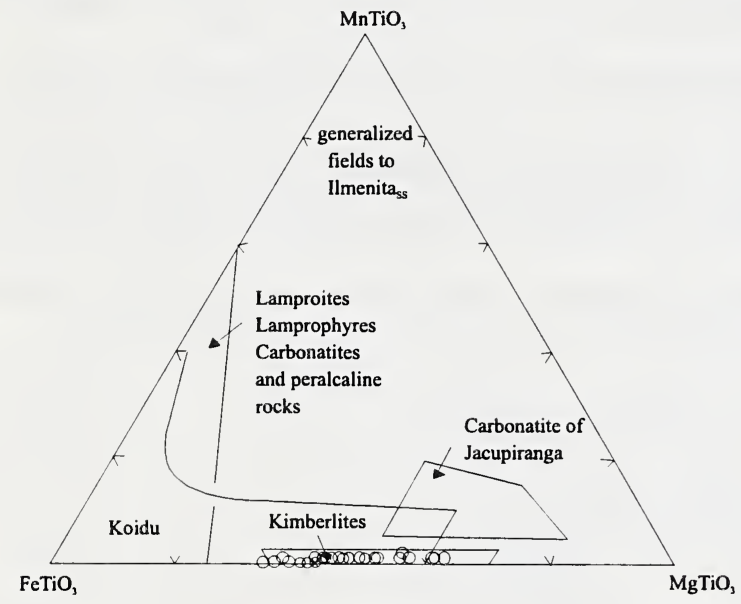

Figure 4: $\mathrm{MgTiO}_{3}-\mathrm{FeTiO}_{3}-\mathrm{MnTiO}_{3}$ diagram for ilmenites. Divisions were proposed by Tompkins \& Haggerty (1985).

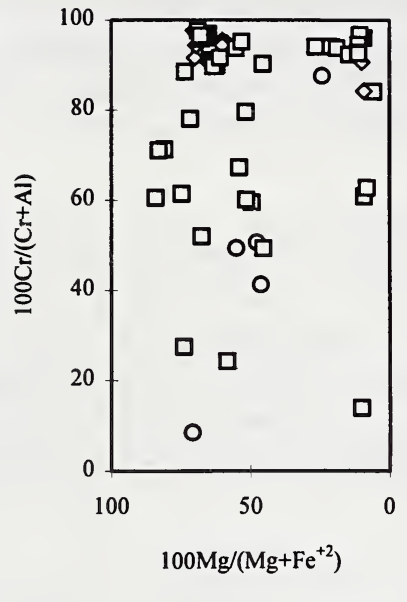

Figure 3: \#Cr versus \#Mg diagram for spinels. Circle, kimberlite; square, mafurite; diamond, ugandite. 